\title{
Cellular organization of normal mouse liver: a histological, quantitative immunocytochemical, and fine structural analysis
}

\author{
Janie L. Baratta $\cdot$ Anthony Ngo $\cdot$ Bryan Lopez $\cdot$ \\ Natasha Kasabwalla $\cdot$ Kenneth J. Longmuir · \\ Richard T. Robertson
}

Accepted: 8 February 2009/Published online: 3 March 2009

(c) The Author(s) 2009. This article is published with open access at Springerlink.com

\begin{abstract}
The cellular organization of normal mouse liver was studied using light and electron microscopy and quantitative immunocytochemical techniques. The general histological organization of the mouse liver is similar to livers of other mammalian species, with a lobular organization based on the distributions of portal areas and central venules. The parenchymal hepatocytes were detected with immunocytochemical techniques to recognize albumin or biotin containing cells. The macrophage Kupffer cells were identified with F4-80 immunocytochemistry, Ito stellate cells were identified with GFAP immunocytochemistry, and endothelial cells were labeled with the CD-34 antibody. Kupffer cells were labeled with intravascularly administered fluorescently labeled latex microspheres of both large $(0.5 \mu \mathrm{m})$ and small $(0.03 \mu \mathrm{m})$ diameters, while endothelial cells were labeled only with small diameter microspheres. Neither hepatocytes nor Ito stellate cells were labeled by intravascularly administered latex microspheres. The principal fine structural features of hepatocytes and nonparenchymal cells of mouse liver are similar to those reported for rat. Counts of immunocytochemically labeled cells with stained nuclei indicated that hepatocytes constituted approximately $52 \%$ of all labeled cells, Kupffer cells about $18 \%$, Ito cells about $8 \%$, and endothelial cells about $22 \%$ of all labeled cells. Approximately, $35 \%$ of the hepatocytes contained two nuclei; none of the Kupffer or Ito
\end{abstract}

J. L. Baratta - A. Ngo · B. Lopez · N. Kasabwalla

R. T. Robertson $(\square)$

Department of Anatomy and Neurobiology, School of Medicine,

University of California, Irvine, CA 92697, USA

e-mail: rtrobert@uci.edu

K. J. Longmuir

Department of Physiology and Biophysics, School of Medicine, University of California, Irvine, CA 92697, USA cells were double nucleated. The presence of canaliculi and a bile duct system appear similar to that reported for other species. The cellular organization of the mouse liver is quite similar to that of other mammalian species, confirming that the mouse presents a useful animal model for studies of liver structure and function.

Keywords Albumin · F4/80 - GFAP · Hepatocyte · Immunocytochemistry

\section{Introduction}

The important roles performed by the liver, not only in the storage and release of nutrients but also in the neutralization and elimination of a variety of toxic substances, have prompted investigations of its cellular constituents and organization. Some of these studies have been carried out in human liver, but the importance of having an experimental model system has prompted several investigations of liver organization in laboratory mammals, primarily rats (Blouin et al. 1977; Bouwens et al. 1992; Gard et al. 1985; Geerts 2001; Kawada 1997; Leo and Lieber 1983; Marcos et al. 2004; Sigal et al. 1999; Sleyster and Knook 1982; Wake et al. 1989; Widmann et al. 1972; Wisse 1970, 1972, 1974; Yokota and Fahimi 1981). In the species studied thus far, investigations have demonstrated that the liver is comprised of several different populations of cells. These include the major parenchymal cells, the hepatocytes (Blouin et al. 1977; David 1985; Jones and Mills 1974; Loud 1968; Yokota and Fahimi 1981), and a variety of non-parenchymal resident cells including a population of macrophages termed Kupffer cells (Bouwens et al. 1986; Naito et al. 1997, 2004; Wake et al. 1989; Widmann et al. 1972; Wisse 1974), fat storing cells termed Ito or stellate 
cells (Fahimi 1982; Ito 1973; Kawada 1997; Sato et al. 2003; Senoo 2004), and endothelial cells (Smedsrod et al. 1994; Stöhr et al. 1978; Widmann et al. 1972; Wisse 1972).

In recent years, the use of mice, and particularly genetically engineered mice, in research laboratories has increased markedly. Several studies have used mice in addressing particular questions in liver structure and function (e.g., Bartök et al. 1983; Longmuir et al. 2006; Naito et al. 1997; Robertson et al. 2008; Sigal et al. 1999; Stöhr et al. 1978; Yamada et al. 1990). Many of these studies assume similarities between the mouse and rat liver, but the putative similarities have not, to our knowledge, been demonstrated. Indeed, notable cases of differences between rat and mouse liver have been reported (Stöhr et al. 1978). Because of the important role that will be played by mice in future studies of liver function, we believe it imperative to establish the baseline of normal cellular composition, to serve as a reference for these future studies. The present paper reports the results of an empirical study of normal mouse liver, with emphasis on identifying the constituent populations of cells in the liver by using immunocytochemical markers, determining essential fine structural features of these cells, and determining the relative numbers of the different immunocytochemically identified populations of cells.

\section{Materials and methods}

\section{Materials}

Chemical supplies were purchased from Sigma Aldrich (St. Louis, MO) unless specified otherwise.

\section{Animals}

All animal work was reviewed and approved by the University of California, Irvine, Institutional Animal Care and Use Committee (IACUC) prior to conducting the experiments. Adult (2-4 mo) BALB/c or ICR female mice, obtained from Charles River (Wilmington, CA), body weight approximately 20-25 g, were used for these experiments. Mice were provided standard laboratory mouse food ad libitum, and were housed in a satellite vivarium with standard $12 \mathrm{~h}$ light, $12 \mathrm{~h}$ dark cycles.

\section{Tissue preparation}

For studies of normal structure, 27 mice were deeply anesthetized with sodium pentobarbital (50 mg/kg i.p.). Mice were perfused through the heart or through the portal vein with $10 \mathrm{ml}$ saline, using a pump at $5 \mathrm{ml} / \mathrm{min}$, to clear the liver of blood, then followed with cold $4 \%$ paraformaldehyde in sodium phosphate buffer, $\mathrm{pH} 7.4$ for approximately $15 \mathrm{~min}$. Providing the perfusion was successful and the liver cleared of blood, no differences were detected in morphological features between the two routes of perfusion.

The liver lobes were removed, cut into $2-3 \mathrm{~mm}$ blocks, and fixed in $4 \%$ paraformaldehyde for $1-18 \mathrm{~h}$ before being placed in $30 \%$ sucrose for cryoprotection. Blocks of liver tissue were frozen in $-20^{\circ} \mathrm{C}$ 2-methylbutane in preparation for sectioning with a cryostat. Frozen liver sections were cut on a Reichert-Jung 1800 cryostat at 10-12 $\mu \mathrm{m}$, mounted directly on super frost slides (Fisher Scientific, Pittsburgh, PA), and air dried for 10-30 min before processing for immunocytochemistry, lectin binding, or hematoxylin and eosin (H\&E) staining.

\section{Latex microsphere and liposome injections}

Twelve mice were lightly anesthetized with Ketaminexylazine (100 mg/kg Ketamine; $5 \mathrm{mg} / \mathrm{kg}$ xylazine). Six of these mice received injections into the tail vein of 25$100 \mu \mathrm{l}$ of a saline solution containing Fluorospheres (fluorescently labeled latex microspheres; 2.5\%; Molecular Probes-Invitrogen, Carlsbad CA). Fluorospheres with mean diameters of $0.5 \mu \mathrm{m}$ or of $0.03 \mu \mathrm{m}$ were used, injected either separately or combined as a cocktail comprising equal volumes of the two stock suspensions. Fluorospheres of different sizes carried different fluorophores, either rhodamine or fluorescein. Following postinjection survival periods of $1-5 \mathrm{~h}$, animals were deeply anesthetized with sodium pentobarbital and perfused through the heart as described above.

The other six of these mice received injections of liposomes into the tail vein. Liposomes were prepared as described previously (Longmuir et al. 2006; Robertson et al. 2008) and contained a liver targeting peptide sequence derived from the circumsporozoite protein of Plasmodium berghei. The liposomes were made from a $\mathrm{mPEG}_{5000}$ conjugate of 22:1-PE, prepared by reacting $10 \mu \mathrm{mol}$ di22:1-PE with $20 \mu \mathrm{mol}$ of $\mathrm{mPEG}_{5000}$ carboxylic acid $N$-hydroxysuccinimidyl ester (\#2M4M0H01, Nektar, Huntsville, AL) and $100 \mu \mathrm{mol}$ of triethylamine in dichloromethane. An addition of 1,2-dipalmitoyl-sn-3-phosphatidylethanolamine, labeled with $1.4 \mathrm{~nm}$ gold particles obtained from Nanoprobes, Inc., Yaphank, NY, was used to enable localization of the liposome fragments using electron microscopy.

Immunocytochemistry

Serial sections of liver were cut on the cryostat and collected on Superfrost/Plus coated slides (Fisher Scientific, Pittsburgh, PA) and processed for immunocytochemistry for albumin, biotin, F 4/80, glial fibrillary acidic protein 
(GFAP), or the endothelial cell marker CD-34. Slides with tissue sections were rinsed in Tris buffer three times and blocked for $1 \mathrm{~h}$ in 3\% normal goat serum (InVitrogen, Carlsbad CA) (for albumin, F4/80, CD-34) or 3\% normal rabbit serum (for biotin). Each primary antibody was tested parametrically, in dilutions of Tris buffer in blocking solution, to determine the optimal antibody concentration to be used. The albumin antibody (Bethyl Labs; Montgomery TX) labeled with FITC was used at 1:500; the biotin antibody (Abcam; Cambridge MA) labeled with FITC was used at 1:500; the macrophage (Kupffer cell) antibody F/4/80 (Serotec, Raleigh, NC) was used at 1:1,000; the GFAP antibody (Dako; Carpinteria, CA) was used at 1:3,000; and the CD-34 antibody (Vector Labs) was used at 1:100. Sections were exposed to primary antibodies at room temperature and in the dark, overnight (16-18 h). The following day, slides were rinsed in Tris buffer three times. The sections for F4/80 then were incubated for $2 \mathrm{~h}$ with either Alexa 488 or Alexa 546 goat anti-rat IgG at 1:1,000 (Invitrogen; Carlsbad CA), sections for GFAP were incubated with either Alexa 488 or Alexa 546 goat anti-rabbit, at 1:1,000 and sections for CD-34 were incubated with Alexa 488 goat anti-mouse at 1:1,000. Following incubation, slides were rinsed with Tris buffer and coverslipped with Vectashield anti-fade fluorescent mounting medium with DAPI; DAPI served as a fluorescent (ultraviolet, UV) stain for cell nuclei.

\section{Lectin binding}

Cryotstat cut sections were mounted on slides and rinsed in Tris buffer. Tomato lectin (Vector labs; Burlingame, CA) labeled with FITC was diluted $(1: 5,000)$ in Tris buffer and sections were incubated overnight in the dark. Slides were rinsed in Tris buffer and coverslipped with Vectashield with DAPI.

Hematoxylin and eosin

Slide mounted 8-12 um cryostat sections were dehydrated through absolute alcohol and rehydrated to water. Slides were placed in hematoxylin stain for $4 \mathrm{~min}$, rinsed in water, differentiated in $70 \%$ alcohol and stained in $0.01 \%$ eosin $\mathrm{Y}$ for $2 \mathrm{~s}$, rinsed in $95 \%$ ethanol, dehydrated with absolute ethanol and cleared in xylenes for $15 \mathrm{~min}$ before coverslipping.

\section{Electron microscopy}

Liver tissue from nine animals was used for electron microscopic studies. Six of these animals had received intravenous injections of liposomes, as described above. Following perfusion with saline followed by $4 \%$ paraformaldeyde, tissue was post-fixed in $4 \%$ paraformaldehyde and $0.5 \%$ glutaraldehyde. Tissue blocks were cut on a Vibratome at $50 \mu \mathrm{m}$. Some sections were processed using a gold-enhancement kit (Goldenhance-EM; Nanoprobes Inc., Yaphank, NY) following the protocols described by the manufacturer. Other sections were processed for immunocytochemistry using the F4-80 or GFAP antibodies. Sections were then placed in $1 \%$ osmium tetroxide for $30 \mathrm{~min}$, embedded in epoxy, cut at $800 \mathrm{~nm}$, and stained with uranyl acetate and lead citrate to enhance contrast. These thin sections were inspected on a Phillips EM-10 electron microscope equipped with a Gatan digital camera.

\section{Dissociated cell staining}

Mice aged 30 days to adult were deeply anesthetized with sodium pentobarbital and perfused through the portal vein with $25 \mathrm{ml}$ cold $0.1 \mathrm{M}$ EDTA in calcium free DMEM followed by $25 \mathrm{ml}$ warm $\left(37^{\circ} \mathrm{C}\right) 0.05 \%$ collagenase II in DMEM with calcium. Liver pieces were removed, minced and incubated with the collagenase medium at $37^{\circ} \mathrm{C}$ for $15 \mathrm{~min}$. Tissue was centrifuged at $1,500 \mathrm{rpm}$ for $5 \mathrm{~min}$, the collagenase medium was removed, and the cells re-suspended in DMEM. The tissue was dissociated and strained through a $100 \mu \mathrm{m}$ mesh to eliminate clumps of cells. The cells were then stained with trypan blue for 2 min before photographing and counting using a bright field microscope.

\section{Image collection and processing}

Slides were examined using bright field illumination (H\&E) or fluorescence illumination with rhodamine, fluorescein, or ultraviolet (DAPI) filter cubes. Digital images were captured using a Nikon DS 5M digital camera and imported into Adobe Photoshop. When creating photographic plates for illustrations, brightness and contrast were adjusted for uniformity within a plate; no other alterations of images were done.

\section{Quantitative assessments}

Relative numbers of each of the different populations of cells were estimated by counting the number of nuclei of immunocytochemically labeled cells and correcting the raw counts by using the method of Abercrombie (1946). Sections of $12 \mu \mathrm{m}$ thickness, immunocytochemically labeled with a cell specific antibody and with DAPI nuclear stain, were examined. Digital images were collected using a $40 \times$ lens and imported into Photoshop. These images included an area of $46,800 \mu^{2}(260 \mu \mathrm{m} \times 180 \mu \mathrm{m})$. Cells that displayed clear immunocytochemical labeling along with distinct DAPI positive nuclei were identified and their 
Fig. 1 Photomicrographs of $12 \mu \mathrm{m}$ thick cryostat sections of mouse liver tissue. a Bright field image of an H\&E stained section showing normal liver architecture, and components of basic liver lobules, with portal area and central venule.

b Another H\&E stained section at higher magnification. c Bright field image showing profiles in a portal area, including branch of portal vein $(p v)$, branch of hepatic artery $(h a)$, and a small bile ductule $(b d)$. d Fluorescein optics showing Alexa 488 labeling of albumin immunoreactivity of hepatocytes; note the bright green packets of immunoreactivity in cytoplasm surrounding large round nuclei (white arrows) vacant of staining. e Fluorescein optics showing Alexa 488 labeled F4-80 immunoreactivity of putative Kupffer cells. f Alexa 488 labeled GFAP positive Ito stellate cells. g Fluorescein labeled tomato lectin staining of cell borders including endothelial cells of sinusoidal capillaries. $c v$ central venule, $p a$ portal area, $p v$ portal venule. Calibration bar in a $100 \mu \mathrm{m}$; bar in $\mathbf{c} 25 \mu \mathrm{m}$; bar in $\mathbf{g} 50 \mu \mathrm{m}$ for $\mathbf{b}$ and $\mathbf{d}-\mathbf{g}$
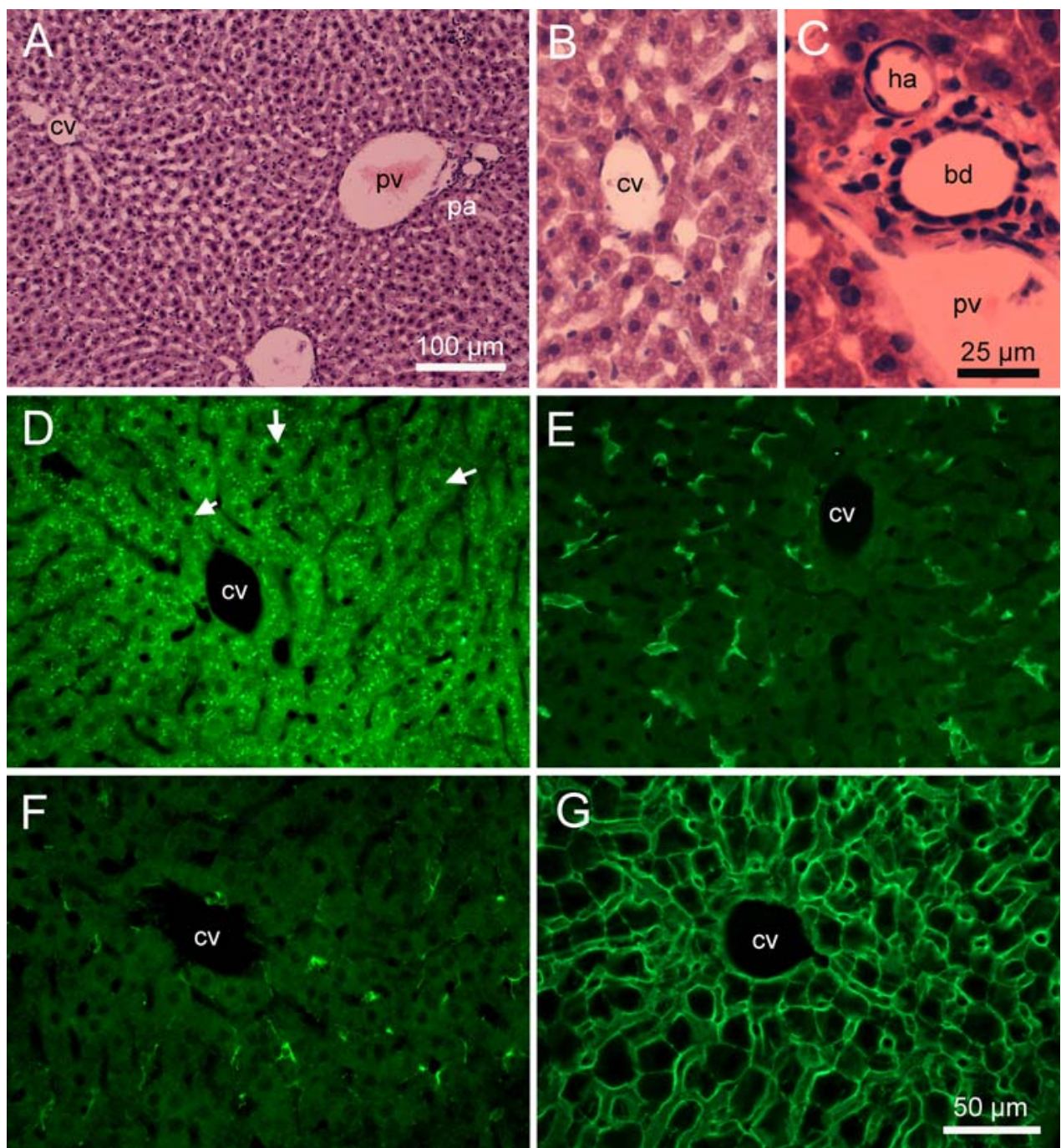

positions marked on an overlaid sheet in Photoshop. Diameters of DAPI stained nuclei were measured using the Nikon DS-5M software for two point distances or from Photoshop images, using a reticule. The number of labeled cells (defined as DAPI stained nucleus amid immunocytochemically labeled cytoplasm) in each section was adjusted by the formula presented by Abercrombie:

$P=A \frac{M}{L+M}$

in which $P$ is the calculated average number of nuclei per region, $A$ the crude count of number of nuclei of labeled cells per section, $M$ the tissue section thickness, and $L$ the average diameter of nuclei.

Numbers of immunocytochemically and DAPI labeled cells were determined for more localized regions of the liver, using the liver acinus scheme of Rappaport et al. (1954). Three zones of approximate equivalent areas were identified in a liver acinus, including zone 1 close to the portal area, zone 3, around the central venule, and a zone 2 situated between zones 1 and 3. Photoshop images were analyzed by placing a graticule, measuring $7,500 \mu \mathrm{m}^{2}$ $(50 \mu \mathrm{m} \times 150 \mu \mathrm{m})$, over each of the zones and determining the numbers of labeled cells in each area.

\section{Results}

Histological organization of normal mouse liver

Sections of mouse liver stained with a standard hematoxylin and eosin (H\&E) procedure reveal patterns of cellular labeling similar to what has been reported for other mammalian species. Portal areas, containing elements of the hepatic triad, that is one or more small branches of the portal vein, a branch of the hepatic artery, and a small bile duct, along with lymphatic vessels and a very small amount of connective tissue, could be identified (Fig. 1a, c). The presence of portal areas along with central venules provided evidence of a lobular structure to the mouse liver. 
Liver cells are arranged in plates or cords, and are seen radiating from the regions of central venules (Fig. 1a, b, d) and extending to the portal areas. The plates or cords of cells are separated by sinusoidal capillaries (Fig. 1g).

Tissue processed with H\&E (or with the fluorescent DAPI stain, see below) reveals distinctly stained nuclei of varied shapes. Most common are cells having one, or sometimes two, large round to slightly oval nuclei. Also detected in the H\&E stained, or DAPI labeled, sections are other cells with smaller and darkly staining oval or oblong nuclei.

Immunocytochemical techniques were used to identify different populations of cells within the liver tissue. As shown in Fig. 1d, cells containing the large round nuclei were labeled by an antibody to albumin. Albumin immunoreactivity appeared as small puncta of intense fluorescence within the cytoplasm of virtually all of these cells (Fig. 1d), although the numbers of puncta as well as their apparent intensity displayed some variation between cells. Because of their immunoreactivity to albumin antibodies, these cells with large round nuclei were deemed to be hepatocytes (Yokota and Fahimi 1981).

Figure 1e shows immunoreactivity to the F4-80 antibody, which is known to label macrophages in other organs and labels some of the cells containing dense oblong nuclei in liver sections. The F4-80 positive cells were distributed throughout the liver lobules but were always associated with a sinusoidal capillary. Within the liver lobules, F4-80 positive cells were more frequently encountered in regions close to the portal area (region 1 of Rappaport et al. 1954) and were more sparse in regions closer to the central venule (region 3). Because their morphological features and F4-80 immunoreactivity are similar to macrophages described in other species, these F4-80 positive cells were deemed to be Kupffer cells (Austyn and Gordon 1981; von Kupffer 1898).

Cells immunoreactive for glial fibrillary acidic protein (GFAP) also contained small oblong nuclei and also were distributed throughout the liver (Fig. 1f). The GFAP positive cells were encountered less frequently than were the F4-80 positive cells. These cells were deemed to be the stellate cells of Ito (Gard et al. 1985; Ito 1973; Neubauer et al. 1996).

Endothelial cells were identified by a combination of CD34 immunoctochemistry and DAPI labeling of nuclei. As shown in Fig. 2a and b, the CD-34 immunoreactivity appears as a cell surface marker and clearly outlines sinusoidal capillaries in liver tissue. The CD-34 immunoreactivity is associated with small and oval or oblong DAPI stained nuclei (arrows) and clearly are distinct from the large round nuclei that are characteristic of the parenchymal hepatocytes. Figure $2 \mathrm{c}-\mathrm{e}$ presents a case in which a mouse received an intravascular injection of small $(0.03 \mu \mathrm{m})$ rhodamine labeled latex microspheres, and the tissue later sectioned and processed for CD-34 immunoreactivity. A comparison of
Fig. $2 \mathrm{c}$ and d demonstrates that these smaller latex microspheres appear to label intensely the endothelial cells. Co-labeling of endothelial cells by green Alexa 488 CD-34 immunoreactivity, red rhodamine labeled latex microspheres, and blue DAPI labeled nuclei is illustrated in the higher magnification photomicrograph of Fig. 2f.

Further immunocytochemical characterization of liver cells

The issue of whether the immunocytochemical markers resulted in overlapping populations of cells was addressed. As was shown in Fig. 1, hepatocytes are labeled by immunoreactivity for albumin. Figure $3 a$ and $b$ show two views of the same section, with rhodamine optics to show immunoreactivity for albumin (Fig. 3a) and under fluorescein optics to show immunoreactivity for biotin (Fig. 3b). Similar to the pattern for albumin, biotin labeling appeared punctate and also appeared to label most cells containing large round nuclei (Fig. 3b). Figure $3 \mathrm{c}$ presents a merger of the images in $3 \mathrm{a}$ and $3 \mathrm{~b}$, along with an ultraviolet image showing the DAPI labeled blue nuclei, and demonstrates that virtually all cuboidal cells with large round nuclei are labeled with antibodies to albumin and also to biotin. These markers are found within the same cells, although the intracellular distribution of green biotin puncta was slightly different from the intracellular distribution of red albumin related puncta.

Albumin immunoreactivity was not found to co-express with immunoreactvity to F4-80, GFAP or CD-34

Photomicrographs in Fig. 3d-f demonstrate that F4-80 labeled cells are a separate population from the GFAP labeled cells. The GFAP antibody labels a population of cells with relatively small and oblong nuclei, and with slender and widely branching cellular processes (Fig. 3d). As noted above, these are the stellate cells identified by Ito (Fahimi 1982; Gard et al. 1985; Geerts et al. 1990; Ito 1973; Kawada 1997; Neubauer et al. 1996). The F4-80 antibody labels a population of cells (Bouwens et al. 1986; Naito et al. 1997; Widmann et al. 1972) that also displays small oblong nuclei, but these cells display widely branching but somewhat broader dendritic processes (Fig. 3e). The photomicrographs of Fig. 3d and e are of the same section, processed for each antibody and using secondary antibodies with different fluorescent labels. When the two images are combined (Fig. 3f) it can be seen that the two labels are associated with distinctly different cells.

The issue of the distinct populations of cells labeled by F4-80 or by GFAP was further explored in animals that received intravascular injections of relatively large $(0.5 \mu \mathrm{m})$ fluorescently labeled latex microspheres. These 
Fig. 2 Fluorescence

photomicrographs showing characteristics of endothelial cell labeling. a Merged image showing Alexa 488 labeled CD34 immunoreactivity (in green) and DAPI stained cell nuclei (in blue). b Similar section as in a, but viewed at higher magnification. Note the many large round DAPI stained nuclei of hepatocytes. In addition, white arrows indicate several smaller and ovoid DAPI stained nuclei associated with the CD-34 positive endothelial cells. c CD-34

immunoreactivity of endothelial cells of liver. d Same section as in $\mathbf{c}$ viewed under rhodamine optics, showing pattern of fluorescently labeled latex small $(0.03 \mu \mathrm{m})$ microspheres. e Same section as shown in $\mathbf{d}$ and e, with merger of images viewed with fluorescein (green CD-34), rhodamine (red fluorescent latex microspheres) and ultraviolet (blue DAPI) optics. White arrow indicates the location of a putative endothelial cell nucleus, in c, $\mathbf{d}$ and e. f Merged image similar to e but at higher magnification. Arrows indicate two putative endothelial cell nuclei. Calibration bar in a $100 \mu \mathrm{m}$. Bar in e $50 \mu \mathrm{m}$ for c, d, and e. Bar in f $50 \mu \mathrm{m}$ for $\mathbf{b}$ and $\mathbf{f}$
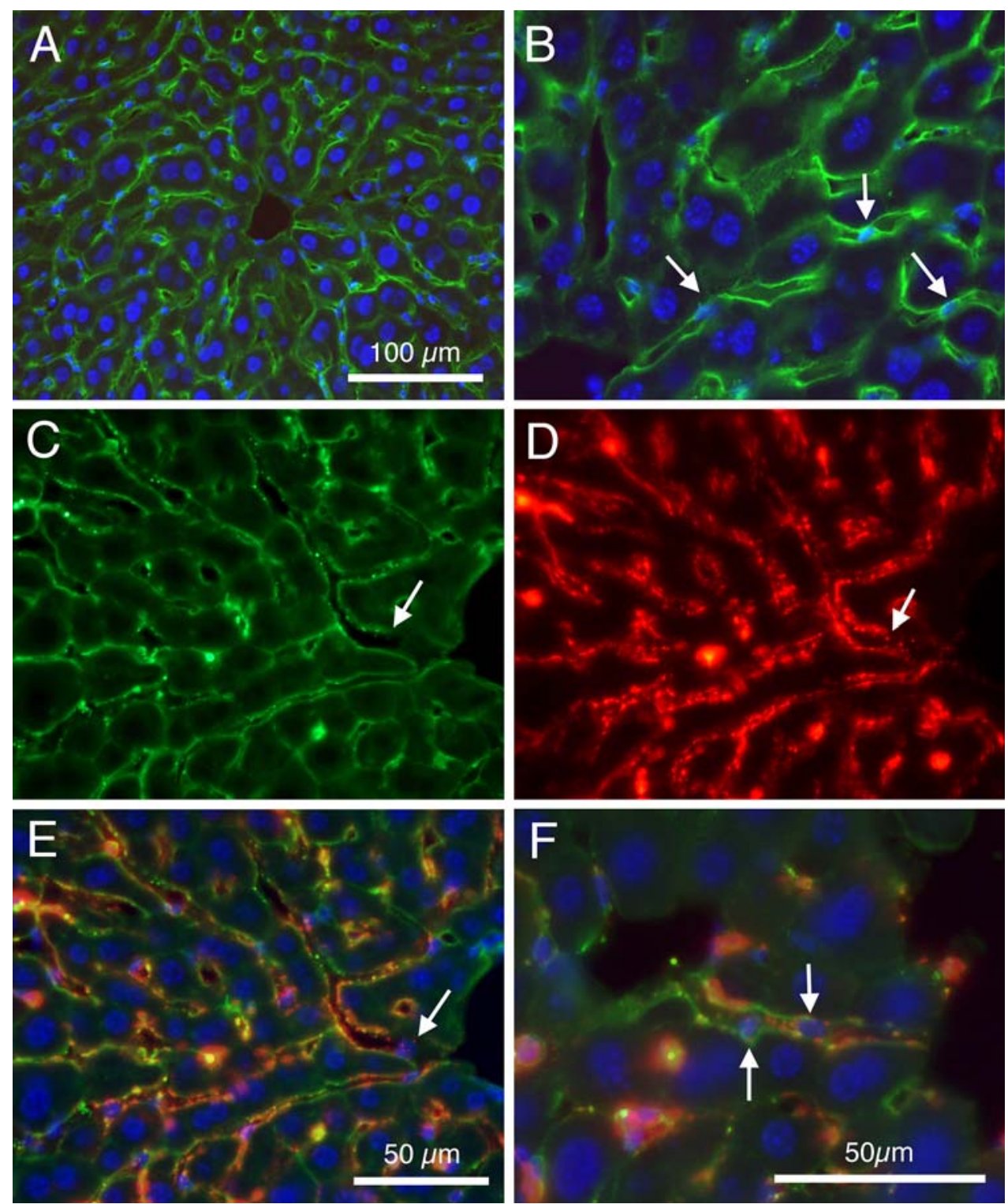

larger microspheres do not label endothelial cells, as do the smaller $(0.03 \mu \mathrm{m})$ microspheres as shown in Fig. 1 , but do label macrophages throughout the body. In sections from the livers of these animals, the rhodamine (red) labeled microspheres could be seen contained within cell bodies. These sections were processed for immunocytochemistry. Figure $3 \mathrm{~g}$ demonstrates that virtually all cells containing red microspheres were labeled with the F4-80 antibody, although not every F4-80 positive cell contained visible microspheres. In contrast, microspheres were not associated with GFAP labeled cells (Fig. 3h).

Double nucleated cells

The issue of determining whether these cells were double nucleated was addressed by studying immunocyto- chemically identified cell types along with DAPI staining of cell nuclei.

Figure $4 \mathrm{a}$ presents a merged image of a section taken using the fluorescein filter set to show tomato lectin binding, which labels the extracellular glycoprotein layer surrounding virtually all liver cells (McMillan et al. 1988), and the UV filter set to reveal DAPI labeling of nuclei. The white arrows indicate several figures that appear to be double nucleated cells. Figure $4 \mathrm{~b}$ shows a similar section, but this section was also processed for immunocytochemical labeling of albumin in red. The white arrows indicate structures, bordered by tomato lectin, containing albumin, and also containing two DAPI stained nuclei. Analysis of 1869 albumin positive cells reveals the presence of double nuclei detected in the plane of the section of 455 of these cells, or approximately $24 \%$. Nuclei of albumin or biotin 

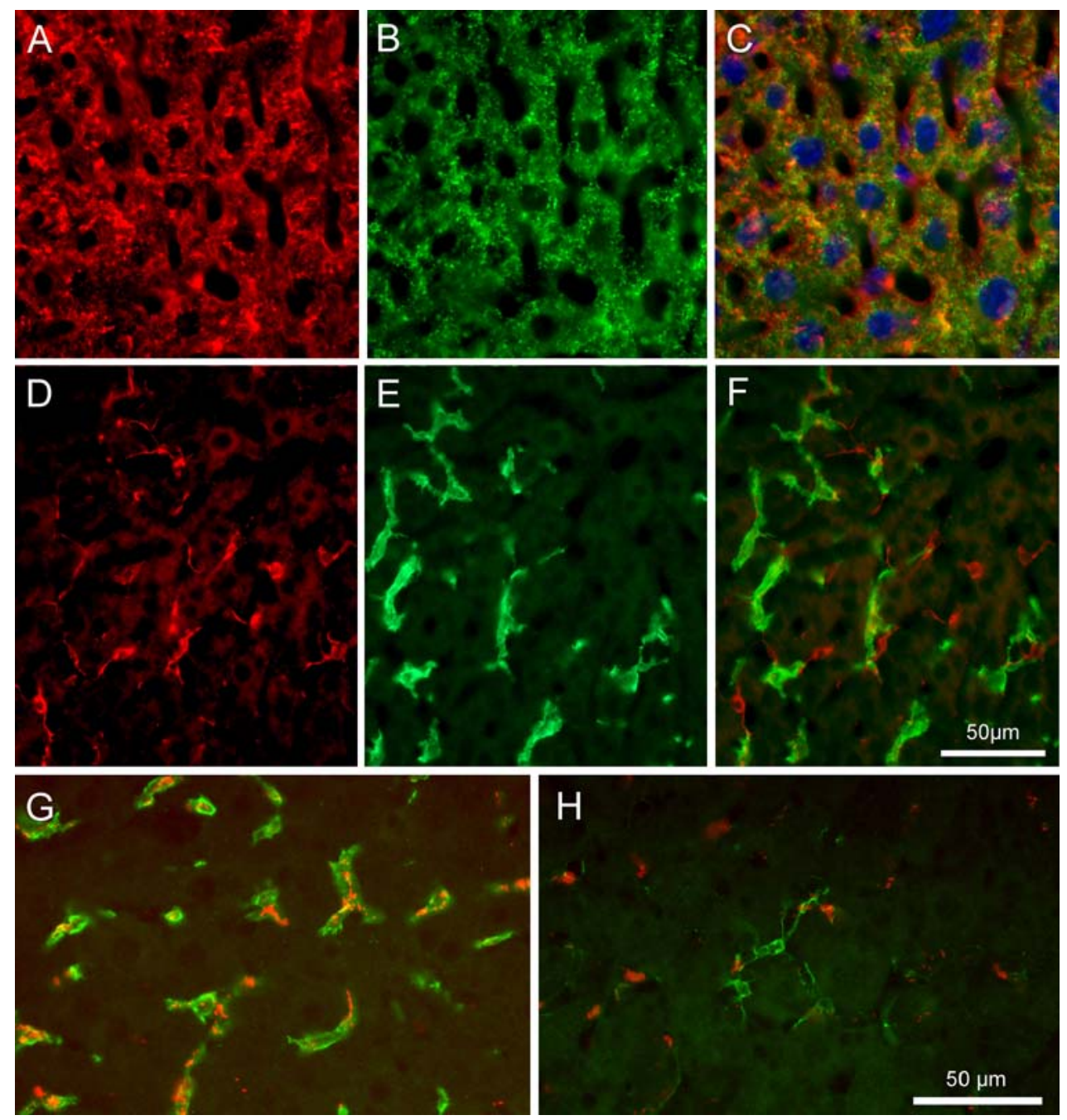

Fig. 3 Fluorescence photomicrographs showing cell specific labeling. a Red Alexa 546 labeled antibody to albumin, demonstrating that virtually all cells containing round nuclei express albumin. b Same section as a viewed under fluorescein optics to show Alexa 488 labeled biotin immunocytochemistry. $\mathbf{c}$ Merged images from $\mathbf{a}$ and $\mathbf{b}$, demonstrating that virtually all cells containing round nuclei appear co-labeled with albumin and biotin. d Section processed with Alexa 546 labeled antibody to GFAP; note the labeled cells with stellate morphological features. e Same section as shown in d, but viewed under fluorescein optics and showing F4-80 labeled cells. f Merged

positive cells were round, with an average diameter of $9.8 \mu \mathrm{m}$. In general, the nuclei of single nucleated cells appeared to have slightly greater diameters than did the nuclei of double nucleated cells, although this was not a statistically significant difference.

In other cases ( $n=4$ animals), livers were prepared for dissociated cell suspensions and stained with Trypan blue. Figure $4 \mathrm{c}$ presents an example of several liver cells, some of which appear to contain only one nucleus (black arrows) while others contained two nuclei (white arrows). Counts of these preparations reveal that approximately $35 \%$ of the dissociated cells (259 of 743) are double nucleated. images from $\mathbf{d}$ and $\mathbf{e}$, demonstrating the two immunocytochemical procedures label distinctly separate populations of cells. g Section from an animal that received intravenous injections of rhodamine labeled fluorescent latex large $(0.5 \mu \mathrm{m})$ microspheres, and then processed for F4-80 immunocytochemistry. Note red microspheres associated with green F4-80 labeled cells. h Section from same animal as $\mathbf{g}$, but processed for GFAP immunocytochemistry. Note red microspheres appear separate from GFAP labeled cells. Calibration bar in $\mathbf{f} 50 \mu \mathrm{m}$ for images $\mathbf{a}-\mathbf{f}$; calibration bar in $\mathbf{h} 50 \mu \mathrm{m}$ for $\mathbf{g}$ and $\mathbf{h}$

Further, evidence of double labeled hepatocytes was also obtained from electron microscopic studies of liver cells, as shown in Fig. 4d.

The possibility of other cell types containing double nuclei was examined using cell specific immunocytochemistry. Figure $4 \mathrm{e}$ presents an example of a merged image showing F4-80 positive cells with DAPI labeled nuclei. The nuclei of F4-80 positive cells typically were ovoid in shape, with a long axis that averaged $7.9 \mu \mathrm{m}$ and a short axis of $4.5 \mu \mathrm{m}$. Of $355 \mathrm{~F} 4-80$ cells examined, there were no instances of cells with two nuclei. Similarly, Fig. 4f presents a merged image showing GFAP positive 

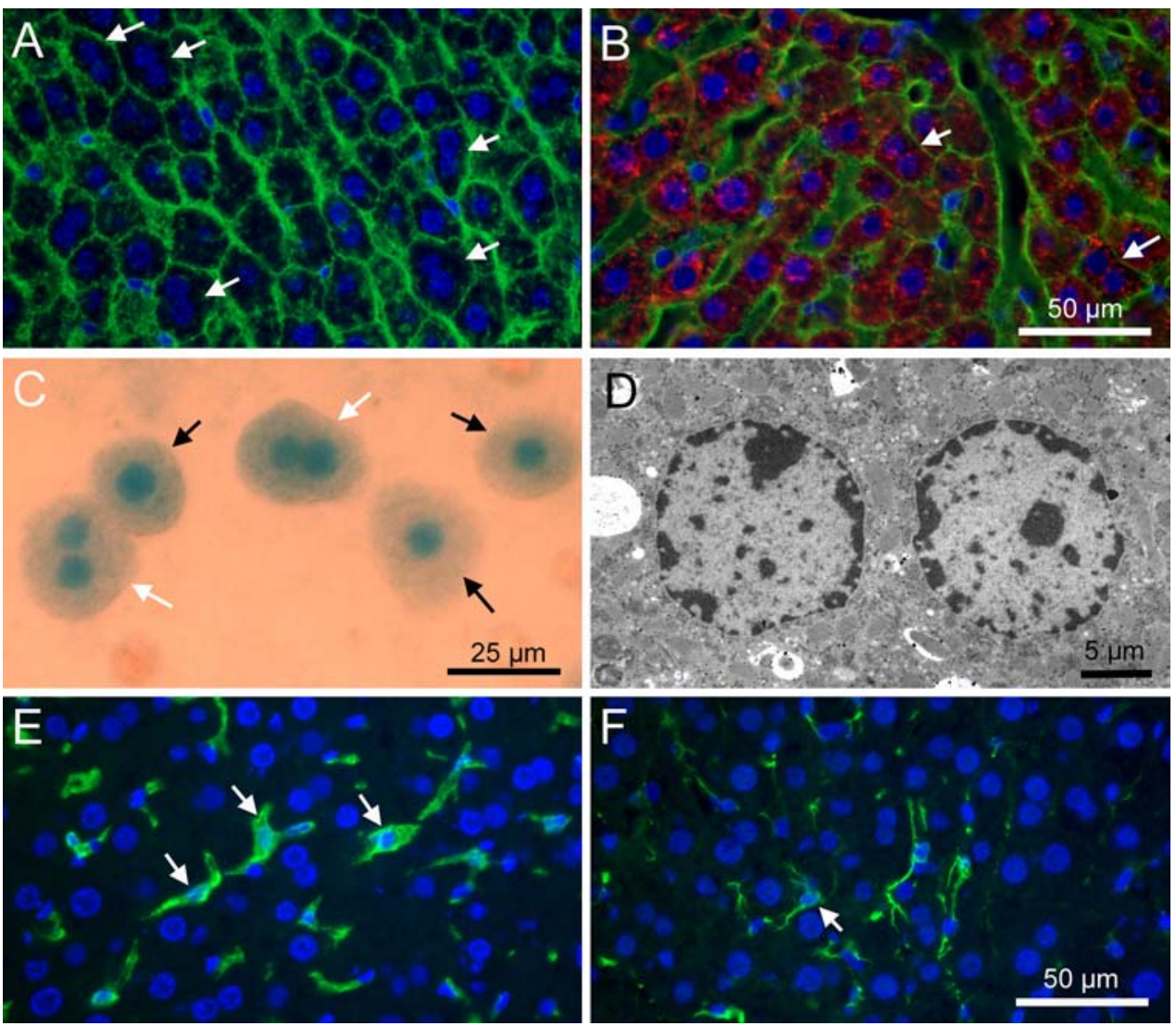

Fig. 4 Evidence for double nucleated cells in liver tissue. a Merged image shows green fluorescein labeled tomato lectin labeling of cell borders and blue DAPI staining of nuclei in a liver tissue section. White arrows indicate structures that appear to be cells with double nuclei. b Merged image showing tissue labeled by a combination of tomato lectin binding (green) to reveal cell borders, and albumin immunocytochemistry (red) along with blue DAPI labeled nuclei. White arrows indicate several albumin positive cells within tomato lectin borders that display double nuclei. c Trypan blue stained

cells. Nuclei of GFAP positive cells also were ovoid or oblong in shape, with a long axis that averaged $6.3 \mu \mathrm{m}$ and a short axis of $4.1 \mu \mathrm{m}$. Of the 147 GFAP positive cells that were examined, none showed evidence of more than one nucleus. Studies of CD-34 labeled endothelial cells with DAPI stained nuclei revealed that nuclei of these cells also displayed oblong shapes, with a long axis that averaged $7.2 \mu \mathrm{m}$ and a short axis of $3.9 \mu \mathrm{m}$. The CD-34 positive cells showed no clear evidence of double labeled cells. However, the borders between adjacent endothelial cells were often difficult to discern, and so it is difficult to conclude that no double labeled endothelial cells exist.

\section{Relative numbers of immunocytochemically identified} cells

Numbers of immunocytochemically identified cells were determined for sets of $12 \mu \mathrm{m}$ thick sections, viewed with a

dissociated liver cells. Note three cells with single nuclei (black arrows) and two cells with double nuclei (white arrows). d Electron micrograph of two nuclear profiles within a liver cell. e Merged images, showing cells double labeled with F4-80 (green Alexa 488 label) and the blue DAPI labeled nuclei. f Merged image showing cells double labeled with GFAP (green) and the blue DAPI labeled nuclei. White arrows in $\mathbf{e}$ and $\mathbf{f}$ indicate single nucleated cells. Calibration bar $50 \mu \mathrm{m}$ for $\mathbf{a}$ and $\mathbf{b}$, and for $\mathbf{e}$ and $\mathbf{f}$. Calibration bar in c $25 \mu \mathrm{m}$; bar in $\mathbf{d} 5 \mu \mathrm{m}$

$40 \times$ lens, in an area of $46,800 \mu \mathrm{m}^{2}(260 \mu \mathrm{m} \times 180 \mu \mathrm{m})$, and the raw numbers corrected by the method of Abercrombie (1946). As shown in Fig. 5, an average of 33.4 cells with albumin positive cytoplasm and a DAPI labeled nucleus was calculated for this field region. The F4-80 positive cells comprised a smaller population, with an average of 12.6 cells per field. The GFAP positive cells were the least frequent population, with an average of 7.1 cells in each field. Endothelial cells, identified by a combination of DAPI labeled nuclei and the CD-34 antibody, were frequently encountered, with an average of 21.8 cells in each field. Wandering or temporarily 'fixed' leukocytes, including the 'pit' cells, were not included in this analysis. Because the Abercrombie (1946) correction factor was employed, it is possible to compare the numbers of cells labeled by each of these methods. Thus, the albumin positive cells constituted about $52 \%$ of all immunocytochemically labeled cells, the endothelial cells about $22 \%$ of 
labeled cells, F4-80 cells were abut $18 \%$ of all labeled cells, and the GFAP positive cells constituted about $8 \%$ of all labeled cells.

The above analysis was a summary of numbers of positively labeled cells across all fields of the liver. Other investigators studying liver from other mammalian species have noted that the distributions of some populations of cells vary between the three 'zones' that comprise the liver acinus (Rappaport et al. 1954). These include a region surrounding the portal area (see Fig. 1a) termed zone 1, a region surrounding the central vein, termed zone 3 , and a region intermediate between the two, termed zone 2 . Numbers of positive cells were counted in $7,500 \mu \mathrm{m}^{2}$ $(50 \mu \mathrm{m} \times 150 \mu \mathrm{m})$ areas in each of these zones. Numbers of albumin positive cells were remarkably consistent in different zones of the liver lobule. Numbers of F4-80 positive cells displayed variation between different regions of the liver, with more cells observed in zone 1 ( 4.5 per $\left.7,500 \mu \mathrm{m}^{2}\right)$ than in zone $2\left(3.9 / 7,500 \mu \mathrm{m}^{2}\right)$ or zone $3(3.7 /$ $\left.7,500 \mu \mathrm{m}^{2}\right)$. Numbers of GFAP positive cells were quite variable, with no consistent difference observed between the different zones. Numbers of CD-34 positive endothelial cells did not vary between regions.

\section{Fine structural features of liver tissue}

An analysis of the fine structural features of hepatocytes and non-parenchymal cells was undertaken using electron microscopic techniques. Figure 6a presents a low magnification electron micrograph of an hepatocyte, showing a typical large round cell nucleus along with cytoplasmic organelles including both smooth (SER) and rough (RER)

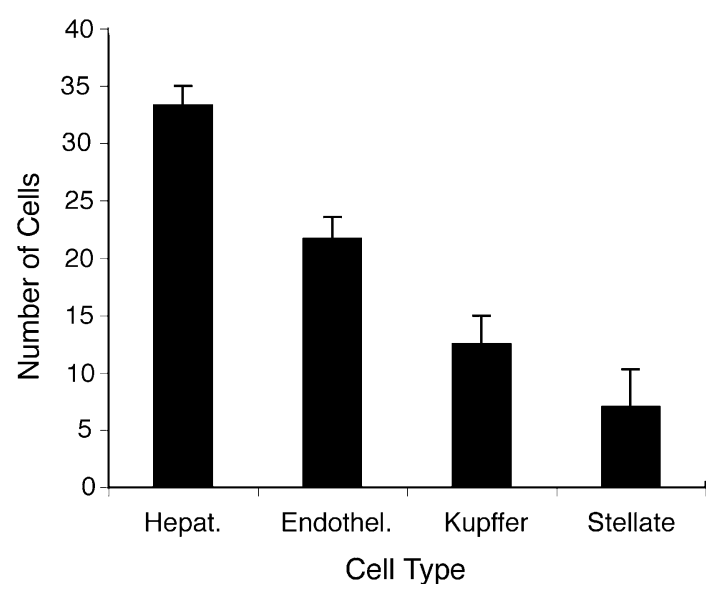

Fig. 5 Histograms summarizing results of counts of immunocytochemically identified cells with DAPI stained nuclei. The $Y$ axis shows numbers of cells detected in a region with an area of $48,000 \mu \mathrm{m}^{2}$, and thickness of $12 \mu \mathrm{m}$. Calculated numbers were adjusted using the method of Abercrombie (1946). Data are mean \pm SEM endoplasmic reticulum and many mitochondria (M). Dense glycogen granules appear distributed throughout the cytoplasm. The basal surface of the hepatocyte, neighboring the sinusoidal capillary space, displays a profuse elaboration of microvilli in the space of Disse (D). The space of Disse is situated just under the endothelial layer of the sinusoidal capillary. Figure $6 \mathrm{~b}$ presents a higher magnification view of the space of Disse, and also shows a fragment of an endothelial cell with a fenestration $(\mathrm{F})$ in the endothelial lining.

Adjacent hepatocytes are separated by a narrow intercellular space with occasional intercellular junctional complexes. The intercellular space widens to form canaliculi (Fig. 6c), and occluding junctional complexes adjacent to the canaliculi apparently separate the lumen of the canaliculi from the normal intercellular space, as shown in Fig. 6c. Golgi apparatus was seen occasionally in the cytoplasm adjacent to the canaliculi.

Non-parenchymal cells were also detected with electron microscopic methods, as illustrated in Fig. 7. Kupffer cells were encountered frequently, either situated upon underlying endothelial cells or as part of the lining of the sinusoidal capillaries. Figure $7 \mathrm{a}$ presents an electron micrograph of tissue that had been processed immunocytochemically for F4-80. The immunoreactivity is visible as dark staining on the plasmalemma, which displays folds and pseudopodia. Kupffer cells display large numbers of lysomes, several of which can be seen in the cell in Fig. 7a. Kupffer cells are also shown in Fig. 7d, where adjacent membranes between Kupffer and endothelial cells display no specialized contacts, and in Fig. 7G, where uptake of gold labeled liposomes is demonstrated by the many gold particles in the Kupffer cell cytoplasm, but not in the nucleus.

Ito stellate cells could be identified by the presence of prominent intracellular lipid droplets and filamentous material, as illustrated in Fig. 7b. These stellate cells were situated between endothelial cells and hepatocytes or were intercalated between hepatocytes (as in Fig. 7b).

Endothelial cells were identified by their elongated and flattened nuclei, and by the presence of fenestrations (Fig. 7c) in the cytoplasmic processes that form much of the lining of the sinusoidal capillaries. These fenestrations have diameters of approximately $125-175 \mathrm{~nm}$. Fenestrations did not include membranous diaphragms over the openings; only sparse evidence of a very rudimentary basal lamina was seen associated with endothelial cells. At sites where cell processes from apparent adjacent endothelial cells meet, specialized adhesive intercellular junctional complexes are seen (Fig. 7e). Adhesive contacts are not seen between endothelial cells and hepatocytes or any other non-parenchymal cell. Finally, pit cells are occasionally seen, as illustrated in Fig. 7f. 
Fig. 6 Electron micrographs of liver tissue. a Relatively low magnification electron micrograph showing a portion of an hepatocyte. A large round nucleus of the hepatocyte $(H N)$ is seen in the lower part of the figure. Many profiles of rough endoplasmic reticulum (RER) can be seen throughout the cytoplasm, often intermixed with mitochondria $(M)$. The space of Disse $(D)$ can be seen at the basal surface, just below processes of endothelial cells that border the lumen $(\mathrm{Lu})$. b Relatively high magnification electron micrograph shows a fenestration $(F)$ in the endothelial cell $(E)$ lining, over the space of Disse $(D)$. c Higher magnification electron micrograph illustrating a canaliculus, and adjacent occluding junctions (arrows)
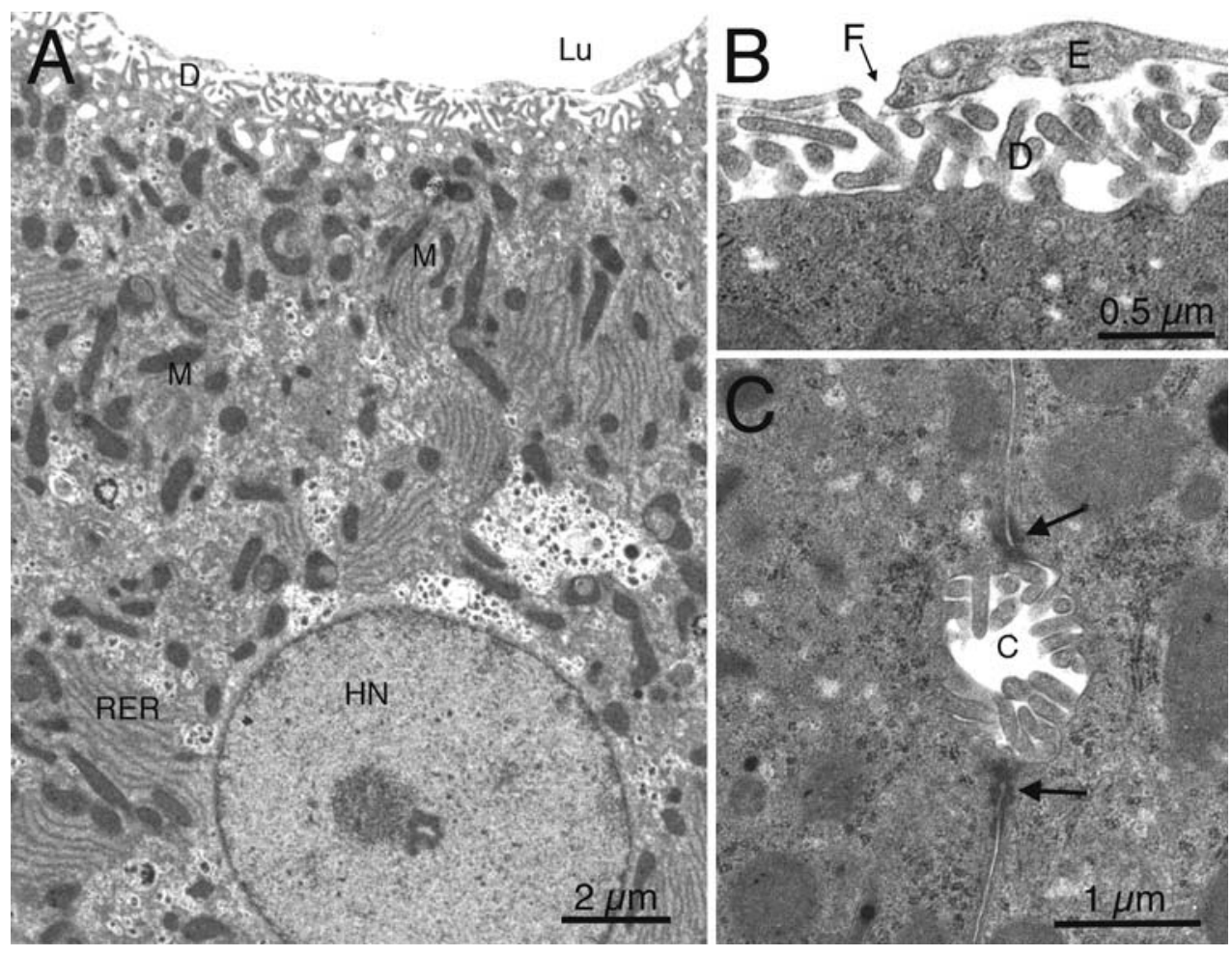

\section{Discussion}

\section{Overview}

The data presented here provide an overview of the histological and fine structural organization of the mature mouse liver. It is clear that the fundamental features of the mouse liver are remarkably similar to the features of liver from other mammalian species. On the one hand, the clear similarities may detract from the noteworthiness of this manuscript; the mouse liver displays the same cellular and subcellular constituents as do the livers of other mammalian species. On the other hand, however, the data presented in this manuscript are vitally important for the interpretation and understanding of other results, using either wild type or genetically engineered mice, and provide a solid reference point against which other data can be interpreted.

Although the very sparse connective tissue within the mouse liver makes recognition of its lobular structure (e.g., Rappaport et al. 1954) a challenge, the major features of the lobules, including the positions of portal areas and central venules, are recognizable (Fig. 1a, c). The types of cells that comprise the mouse liver are similar to those that have been described in other species. The prominent cell type is the hepatocyte, characterized by the presence of intracellular albumin (Bernuau et al. 1985) or biotin. Also found are phagocytic Kupffer cells (von Kupffer 1898), labeled with the F4-80 antibody (Naito et al. 1997), the numbers of which are approximately $35-40 \%$ of the number of hepatocytes. Also studied were the Ito stellate cells (Gard et al. 1985; Ito 1973; Neubauer et al. 1996), whose numbers are about $8-10 \%$ of the number of hepatocytes. As with any organ, endothelial cells form much of the lining of the sinusoidal capillaries. Although the thin squamous endothelial cells do not contribute a great deal to the volume of tissue in the liver, the number of nuclei is approximately $22 \%$ of all liver nuclei and approximately $40 \%$ of the number of hepatocytes. The relative proportions of these cells are similar to figures reported for other species (Bouwens et al. 1986; Geerts 2001; Marcos et al. 2004; Naito et al. 1997; Sato et al. 2003). Further, the biliary system of the mouse liver appears similar to that of other mammalian species, with the presence of canaliculi between adjacent hepatocytes and small bile ductules that form part of portal areas. Thus, although the present investigation did not reveal novel features of liver organization in the mouse, the value of this study is that it establishes baseline data for the mouse and demonstrates the similarities of the histological organization of the mouse liver and of other mammalian species. These data underscore the value of the mouse model for laboratory studies of liver structure and function.

\section{Liver cell types}

Parenchymal cells in the liver are the hepatocytes, while non-parenchymal cells include the Kupffer cells, Ito 

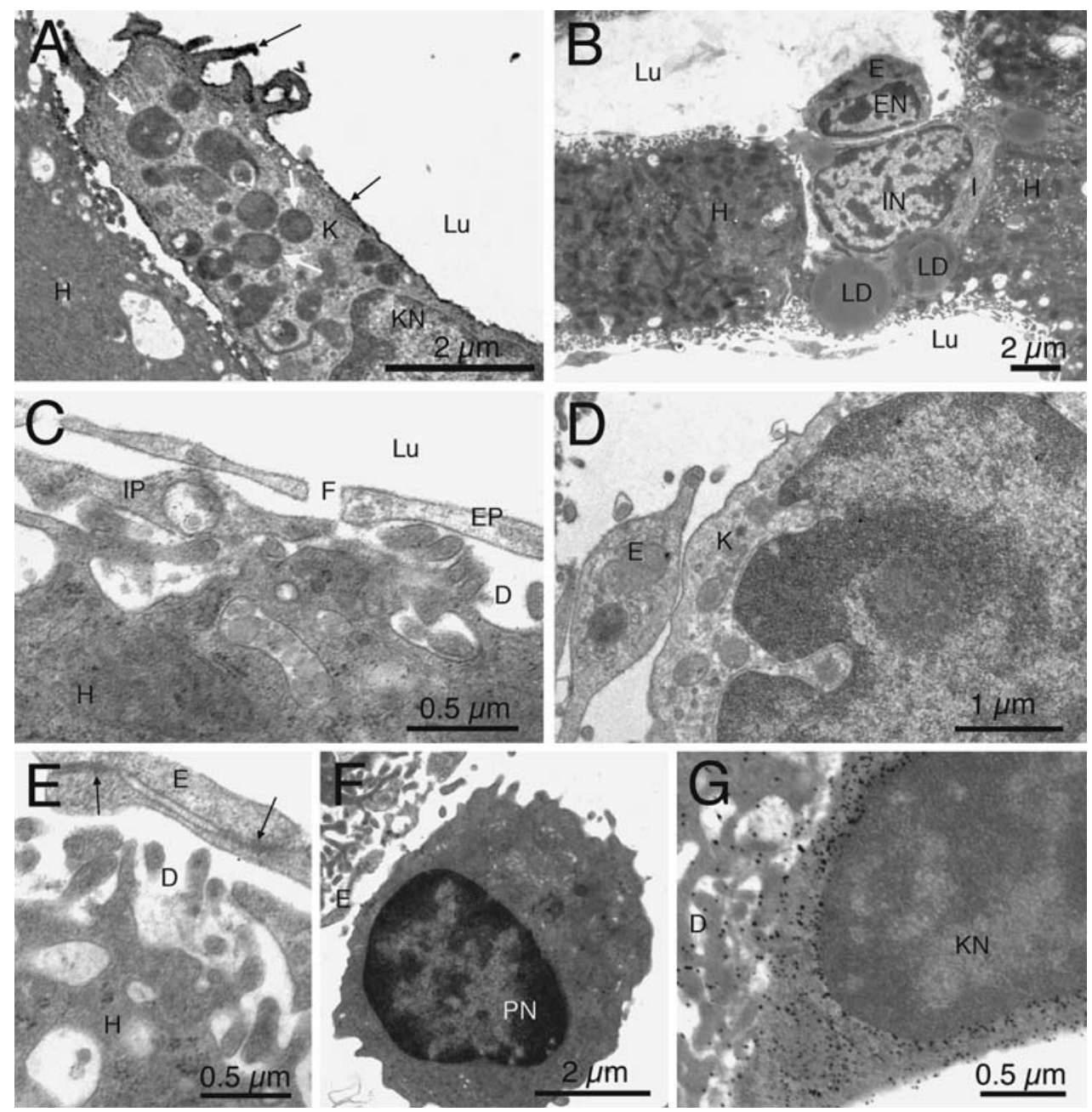

Fig. 7 Electron micrographs of non-parenchymal cells. a Electron micrograph of a section processed immunocytochemically for F4-80, showing cell surface immunoreactivity (black arrows) of a Kupffer cell $(K)$; the nucleus of the Kupffer cell $(K N)$ is visible. White arrows indicate lysomes within the Kupffer cell. The Kupffer cell is situated in the sinusoidal lumen $(L u)$, above an hepatocyte $(H)$. b Micrograph showing an Ito stellate cell $(I)$ situated between two hepatocytes $(H)$ and an endothelial cell $(E)$. The Ito cell is characterized by cytoplasmic lipid droplets $(L D)$. c High magnification electron micrograph showing the space of Disse $(D)$ situated under fenestrated

stellate cells, wandering leukocytes (including a population of lymphocytes, termed the 'pit' cells (Bouwens et al. 1992), and endothelial cells.

Different cell types in the liver were identified based upon their morphological features and by their immunoreactivity. Hepatocytes have long been recognized in $\mathrm{H} \& \mathrm{E}$ stained material as round or cuboidal cells, and recent studies have demonstrated that they contain mRNA for expressing the albumin gene and also are immunoreactive for albumin (Bernuau et al. 1985; Yokota and Fahimi 1981). The present results from mouse are fully compatible with these previous reports. The present results indicate that albumin positive hepatocytes are encountered
$(F)$ endothelial processes $(E P)$ above an hepatocyte $(H)$ and below the capillary lumen $(L u)$. Also seen is a putative Ito cell process $(I P)$. d Close membrane association, but without specialized membrane attachments, between a Kupffer cell $(K)$ and an endothelial cell $(E)$. e Adhering junctions (arrows) between processes of two endothelial cells $(E)$, overlying the space of Disse $(D)$ and an hepatocyte $(H)$. f Pit cell with nucleus $(P N)$ situated in a sinusoidal lumen, adjacent to an endothelial cell $(E)$. g Micrograph showing gold labeled particles associated with engulfed liposomes in a Kupffer cell (Kupffer cell nucleus $K N$ is indicated)

approximately three times more frequently than are Kupffer cells, and about six to seven times more frequently than Ito stellate cells.

Further, the present studies demonstrate that hepatocytes also contain biotin. Biotin appears not to be synthesized by hepatocytes but rather is taken up from food or produced by intestinal flora (Bowman and Russell 2006), and is stored in the liver to support its role in metabolism. The presence of biotin within hepatocytes clearly is important for considerations of its metabolic role, but may also have importance in issues of immunocytochemical methodology. Immunocytochemical studies that use avidin-biotin binding as a step in localizing some antigen of interest may 
yield false positive results due to avidin binding to endogenous biotin rather than to biotinylated secondary antibodies (Ramos-Vara 2005).

The fine structural features of mouse hepatocytes are similar to those reported for other species. Large round nuclei, and occasionally two nuclei, are prominent. Much of the cytoplasm is occupied by mitochondria, both smooth and rough endoplasmic reticulum, and scattered glycogen particles. The basolateral portion of the hepatocyte, which faces the sinusoidal capillaries, displays a rich microvillous elaboration of the plasmalemma; this microvillous border occupies much of the space of Disse. As in other mammalian species, the apical portion of hepatocytes is associated with canaliculi. Canaliculi are formed by a widening of the intercellular space, although the canalicular lumens are set off from the intercellular space by occluding junctions. Small profiles of Golgi apparatus were seen occasionally in the apical cytoplasm close to canaliculi, but we did not detect secretory vesicles associated with canaliculi. The canaliculi are believed to form an anastomosing system, which lead eventually through ducts of Hering into small bile ductules in the portal areas. These small bile ducts are a consistent feature in the portal areas.

Monocyte derived macrophages are found in virtually every organ and tissue of the body, and comprise the diffuse reticulo-endothelial system (Aschoff 1924; Furth et al. 1972). In the liver these macrophages are termed Kupffer cells (von Kupffer 1898). Although originally, these phagocytic cells were likely confused with the stellate cells that would later be identified by Ito (1973), later studies demonstrated that Kupffer cells can be identified by their ability to phagocytose tracer substances, including carbon, India ink, or latex microspheres, and also by their immunoreactivity to the F4-80 antibody. The present studies demonstrated the presence of F4-80 positive Kupffer cells in mouse liver, and electron microscopic studies demonstrated this antibody labels a cell surface marker. Further, the results from studies of double labeling with fluorescently labeled latex microspheres and also from immunocytochemistry have demonstrated conclusively that the Kupffer cells are a population of cells distinct from the Ito stellate (fat storing) cells.

The use of latex microspheres of different diameters was useful in demonstrating that Kupffer cells could be labeled specifically with larger $(0.5 \mu \mathrm{m})$ microspheres, while smaller microspheres $(0.03 \mu \mathrm{m})$ labeled both Kupffer cells and endothelial cells, as demonstrated previously (Wake et al. 1989).

Other investigators (Bouwens et al. 1986, 1992; Sleyster and Knook 1982) have noted that Kupffer cells are not distributed homogenously in the liver and appear to show some variation in regard to their phagocytic activity. These authors (Sleyster and Knook 1982; Bouwens et al. 1992;
Bouwens et al. 1986) have reported that Kupffer cells are more frequently encountered and also are larger in regions around the portal areas than around the central venules. The present data corroborate this finding in the mouse, although the regional differences in the mouse liver appear not as great as the regional differences reported for rat liver.

Ito stellate cells are fat storing cells of the liver, and in the present studies these were identified by immunoreactivity to glial fibrillary acidic protein (GFAP) (Gard et al. 1985; Neubauer et al. 1996). Stellate cells are identifiable by their fine structural features of prominent intracellular lipid droplets and by cytoplasmic filamentous material. The intracellular filamentous material likely forms the basis of their immunoreativity to GFAP and to desmin (Leo and Lieber 1983; Yokoi et al. 1984; de Bleser et al. 1991). Quantitative estimates (Leo and Lieber 1983; Yokoi et al. 1984; de Bleser et al. 1991) indicated that numbers of Ito stellate cells in rat liver were about $10-12 \%$ of hepatocytes, a fraction similar to the present results in mouse. Further, de Bleser et al. (1991) reported that stellate cells were found more frequently in peri-portal areas than in pericentral areas. The present study noted that stellate cells were not distributed homogenously throughout the liver, but a consistent pattern between peri-portal and peri-central regions was not detected.

Endothelial cells are an important cell type in any organ, and certainly so in the liver. Liver endothelial cells are specialized, with the presence of fenestrations that appear aggregated into groups that form 'sieve plates' (Wisse 1972). The very sparse nature of a basal lamina beneath the endothelial cells, along with the absence of diaphragmatic coverings of the fenestrations, allows for apparent relatively free movement of small molecules (less than $125 \mathrm{~nm}$ diameter) between the space of Disse and the capillary lumen. Wisse has demonstrated both small bristle-coated micropinocytotic vesicles and large smooth macropinocytotic vesicles in the endothelial cells. Small latex microspheres, diameter of $30 \mathrm{~nm}$, are not detected in hepatocytes after intravascular injection, although they do appear to label endothelial cells. This suggests that the latex microspheres are taken up by endothelial vesicles, but either do not reach the space of Disse or are not taken up by the hepatocyte microvillous border in the space of Disse.

\section{Double nucleated cells}

The present analysis indicated that a considerable portion of hepatocytes are double nucleated. The percentage gleaned from studies of tissue slices is likely to be an underestimate, however, because although two nuclei in the $X$ or $Y$ planes would be detected easily, if a second nucleus was obscured in the $Z$ plane or found within an 
adjacent section, it would be missed by the techniques employed in this study. Another approach taken in the present studies was to dissociate liver cells, and use the Trypan blue stain to detect double nucleated cells. This analysis yielded higher numbers, of approximately $35 \%$ double nucleated cells. These results are in agreement with other recent studies (Wheatley 1972; Gupta 2000) that have reported that the population of hepatocytes includes many double nucleated cells. The functional significance of double nucleated cells, however, is not clear.

No evidence was revealed to indicate that any other cell type within the liver included double nucleated cells. Analysis of tissue sections immunolabeled with F4-80 for Kupffer cells or with GFAP for Ito stellate cells revealed no evidence of more than one DAPI stained nucleus. Kupffer and stellate cells probably were not detected in the dissociated cell studies, as different steps in the cell dissociation process need to be taken to include these cell populations (Smedsrod et al. 1985; Riccalton-Banks et al. 2003). The thin squamous endothelial cells display extensive spread of cytoplasm and membranes, making the detection of two nuclei within one cell a very difficult endeavor. We are not aware of any examples of double nucleated endothelial cells, and believe they are not likely to exist.

\section{Conclusion}

Genetically engineered mice will play a very important role in future studies of liver function, and so it is vitally important to have baseline reference information on the cellular makeup of normal mouse liver. The present paper, using histological, quantitative immunocytochemical, and fine structural analyses, demonstrates that the cellular organization of the mouse liver is quite similar to that of other mammalian species, confirming that the mouse presents a useful animal model for studies of liver structure and function.

Acknowledgment The work was supported by NIH grant EB003075 .

Open Access This article is distributed under the terms of the Creative Commons Attribution Noncommercial License which permits any noncommercial use, distribution, and reproduction in any medium, provided the original author(s) and source are credited.

\section{References}

Abercrombie M (1946) Estimation of nuclear population from microtome sections. Anat Rec 94:239-247

Aschoff L (1924) Das reticulo/endotheliale system. Ergebn Med Kinderheilk 26:1-118
Austyn JM, Gordon S (1981) F4/80, a monoclonal antibody directed specifically against the mouse macrophage. Eur J Immunol 11:805-815

Bartök I, Töth J, Remenar E, Viragh S (1983) Fine structure of perisinusoidal cells in developing human and mouse liver. Acta Morphol Hung 31:337-352

Bernuau D, Poliard A, Tournier I, Sala-Trepat J, Feldmann G (1985) All hepatocytes are involved in the expression of the albumin gene in the normal adult rat: a demonstration by in situ hybridization and immunoperoxidase techniques. Cell Biol Int Rep 9:31-42

Blouin A, Bolender RP, Weibel ER (1977) Distribution of organelles and membranes between hepatocytes and nonhepatocytes in the rat liver parenchyma. A stereological study. J Cell Biol 72:441455

Bouwens L, Baekeland M, DeZanger R, Wisse E (1986) Quantitation, tissue distribution and proliferation kinetics of Kupffer cells in normal liver. Hepatology 6:718-722

Bouwens L, DeBleser P, Vanderkerken K, Geerts B, Wisse E (1992) Liver cell heterogeneity: functions of non-parenchymal cells. Enzyme 46:155-168

Bowman BA, Russell RM (eds) (2006) Biotin. In present knowledge in nutrition, vol 1, 9th edn. Int Life Sci Inst, Washington DC

David H (1985) The hepatocyte. Development, differentiation, and ageing. Exp Pathol Suppl 11:1-148

De Bleser P, Geerts A, Wisse E (1991) Role of fat-storing cells in hepatic fibrogenesis. Retinoids as possible therapeutic agents. Alcohol Alcohol Suppl 1:3345-3350

Fahimi HD (1982) Sinusoidal endothelial cells and perisinusoidal fatstoring cells: structure and function. In: Arias IM, Popper H, Schachter D, Shafritz DA (eds) The liver: biology and pathobiology. Raven Press, New York, pp 495-506

Furth R, von Cohn ZA, Hirsh JG, Humphry JH, Spector WG, Langevoort HL (1972) The mononuclear phagocyte system: a new classification of macrophages, monocytes, and their precursors. Bull WHO 46:845-852

Gard AL, White FP, Dutton G (1985) Extra-neural glial fibrillary acidic protein (GFAP) immunoreactivity in perisinusoidal stellate cells of rat liver. J Neuroimmunol 8:359-375

Geerts A (2001) History, heterogeneity, developmental biology, and functions of quiescent hepatic stellate cells. Semin Liver Dis 21:311-335

Geerts A, Bouwens L, Wisse E (1990) Ultrastructure and function of hepatic fat-storing and pit cells. J Electron Microsc Tech $14: 247-256$

Gupta S (2000) Hepatic polyploidy and liver growth control. Sem Canc Biol 10:161-171

Ito T (1973) Recent advances in the study on the fine structure of the hepatic sinusoidal wall: a review. Gumma Rep Med Sci 6:119_ 163

Jones AL, Mills ES (1974) Ultrastructural concepts of drug metabolism. I. The hepatocyte: structure and function. Am J Drug Alcohol Abuse 1:111-135

Kawada N (1997) The hepatic perisinusoidal stellate cell. Histol Histopathol 12:1069-1080

Leo M, Lieber C (1983) Hepatic fibrosis after long-term administration of ethanol and moderate vitamin A supplementation in the rat. Hepatology 3:1-11

Longmuir KJ, Robertson RT, Haynes SM, Baratta JL, Waring AJ (2006) Effective targeting of liposomes to liver and hepatocytes in vivo by incorporation of a Plasmodium amino acid sequence. Pharm Res 23:759-769

Loud AV (1968) A quantitative stereological description of the ultrastructure of normal rat liver parenchymal cells. J Cell Biol $37: 27-46$ 
Marcos R, Monteiro RAF, Rocha E (2004) Estimation of the number of stellate cells in a liver with the smooth fractionator. J Microsc 215:174-182

McMillan PN, Hixson DC, Hevey KA, Naik S, Jauregui HO (1988) Hepatocyte cell surface polarity as demonstrated by lectin binding. J Histochem Cytochem 36:1561-1571

Naito M, Hasegawa G, Takahashi K (1997) Development, differentiation, and maturation of Kupffer cells. Microsc Res Techn 39:350-364

Naito M, Hasegawa G, Ebe Y, Yamamoto T (2004) Differentiation and function of Kupffer cells. Med Electron Microsc 37:16-28

Neubauer K, Knittel T, Aurisch S, Fellmer P, Ramadori G (1996) Glial fibrillary acidic protein; a cell type specific marker for Ito cells in vivo and in vitro. $\mathrm{J}$ Hepatol 24:719-730

Ramos-Vara JA (2005) Technical aspects of immunocytochemistry. Vet Pathol 42:405-426

Rappaport AM, Borrowy ZJ, Lougheed WM, Lotto WN (1954) Subdivision of hexagonal liver lobules into a structural and functional unit; role in hepatic physiology and pathology. Anat Rec 119:11-33

Riccalton-Banks L, Bhandari R, Fry J, Shakesheff KM (2003) A simple method for the simultaneous isolation of stellate cells and hepatocytes from rat liver tissue. Mol Cell Biochem 248:97-102

Robertson RT, Baratta JL, Haynes SM, Longmuir KJ (2008) Liposomes incorporating a Plasmodium amino acid sequence target heparan sulfate binding sites in liver. J Pharm Sci 97:3257-3273

Sato M, Suzuki S, Senoo H (2003) Hepatic stellate cells: unique characteristics in cell biology and phenotype. Cell Struct Funct 28:105-112

Senoo H (2004) Structure and function of hepatic stellate cells. Med Electron Microsc 37:3-15

Sigal SH, Rajanshi P, Gorla GR, Saxena R, Sokhi RP, Gebhardt DF, Reid LM, Gupta S (1999) Partial hepatectomy-induced polyploidy attenuates hepatocyte replication and activates cell aging events. Am J Physiol 276:G1260-G1272

Sleyster EC, Knook DL (1982) Relation between localization and function of rat liver Kupffer cells. Lab Invest 47:484-490

Smedsrod B, Pertoft H, Eggertsen G, Sundstrom C (1985) Functional and morphological characterization of cultures of Kupffer cells and liver endothelial cells prepared by means of density separation in Percol, and selective substrate adherence. Cell Tissue Res 241:639-649

Smedsrod B, de Bleser PJ, Braet F, Lovisetti P, Vanderkerken K, Wisse E, Geerts A (1994) Cell biology of liver endothelial and Kupffer cells. Gut 35:1509-1516

Stöhr G, Deimann W, Fahimi HD (1978) Peroxidase-positive endothelial cells in sinusoids of the mouse liver. J Histochem Cytochem 26:409-411

von Kupffer C (1898) Über Sternzellen der Leber. Verhandl Anat Gesellsch 12:80-85

Wake K, Dicker K, Kirn A, Knkook DL, McCuskey RS, Bouwens L, Wisse E (1989) Cell biology and kinetics of Kupffer cells in the liver. Int Rev Cytol 118:173-229

Wheatley DN (1972) Binucleation in mammalian liver. Exp Cell Res 74:455-465

Widmann JJ, Cotran RS, Fahmi HD (1972) Mononuclear phagocytes (Kuffer cells) and endothelial cells. Identification of two functional cell types in rat liver sinusoids by endogenous peroxidase activity. J Cell Biol 52:159-170

Wisse E (1970) An electron microscopic study of the fenestrated endothelial lining of rat liver sinusoids. J Ultrastruct Res 31:125150

Wisse E (1972) An ultrastructural characterization of the endothelial cell in the rat liver sinusoid under normal and various experimental conditions, as a contribution to the distinction between endothelial and Kupffer cells. J Ultrastruct Res 38:528562

Wisse E (1974) Observations on the fine structure and peroxidase cytochemistry of normal rat liver Kupffer cells. J Ultrastruct Res 46:393-426

Yamada M, Naito M, Takahashi K (1990) Kupffer cell proliferation and glucan-induced granuloma formation in mice depleted of blood monocytes by strontium-89. J Leukoc Biol 47:195-205

Yokoi Y, Namihisa T, Kuroda H, Komatsu I, Miyazaki A, Wanatabe S, Usui K (1984) Imunocytochemical detection of desmin in fatstoring cells (Ito cells). Hepatology 4:709-714

Yokota S, Fahimi HD (1981) Immunocytochemical localization of albumin in the secretory apparatus of rat liver parenchymal cells. Proc Natl Acad Sci USA 78:4970-4974 